\title{
Possible role of NF- $\kappa$ B and p53 in the glutamate-induced pro-apoptotic neuronal pathway
}

\author{
Mariagrazia Grilli ${ }^{2}$ and Maurizio Memo ${ }^{*, 1}$ \\ ${ }^{1}$ Division of Pharmacology, Department of Biomedical Sciences and \\ Biotechnologies, School of Medicine, University of Brescia, Brescia, Italy \\ ${ }^{2}$ Schering-Plough Research Institute, San Raffaele Science Park, Milan, Italy \\ * corresponding author : Department of Biomedical Sciences and \\ Biotechnologies, School of Medicine, University of Brescia, Via Valsabbina 19 \\ 25124 Brescia, Italy; e-mail: memo@med.unibs.it
}

Received 25.08.98; revised 24.09.98; accepted 12.10.98 Edited by G. Melino

\begin{abstract}
Apoptosis is now recognized as an important component in many progressive and acute neurodegenerative diseases. Extracellular signals and intracellular mechanisms triggering and regulating apoptosis in neuronal cells are still a matter of investigation. Here we review data from our and other laboratories with the aim to elucidate the nature of some proteins which are known to be involved in cell cycle regulation as well as in promoting degeneration and apoptosis of neurons. The following molecules will be taken into consideration: NF- $k \mathrm{~B}, \mathrm{p} 53, \mathrm{p} 21$ and $\mathrm{MSH}$. These proteins are activated by neurotoxic experimental conditions which involve the stimulation of selective receptors for the excitatory aminoacid glutamate. Thus, we hypothesize their contribution to an intracellular pathway responsible for the glutamateinduced neuronal death. Identification of such mechanisms could be relevant for understanding the apoptosis associated with various neurodegenerative diseases as well as for developing novel strategies of pharmacological intervention.
\end{abstract}

Keywords: cerebellar neurons; cyclin-dependent kinase; excitotoxicity; glutamate; neurodegenerative diseases; tumour suppressor gene

Abbreviations: cdk, cyclin-dependent kinase; CNS, central nervous system; $\mathrm{MSH} 2$, mutS homolog $2 ; \mathrm{NF}-\kappa \mathrm{B}$, nuclear factor kappa B

\section{Introduction}

Apoptosis of neuronal cells has been suggested to be the result of aberrant cell cycle control. This hypothesis stands on several independent lines of reasoning that foster the notion of a link between cell cycle and apoptosis. First, apoptosis is frequently observed in highly proliferative cells such as embryonal cells, hematopoietic cells, and neoplastic cells. Second, some of the morphological features observed during apoptosis, including cell rounding, nuclear envelop breakdown, chromatin condensation, and nuclear lamina disassembly, occur during mitosis. Third, activation of a number of genes that mediate the transition of cells from quiescent to proliferative state is associated with apoptosis. In this regard, it has been shown that apoptosis of neurons may be activated in response to molecular events that lead to transformation of dividing stem cell populations. The relationship between transformation and neurodegeneration originally proposed by Heintz, ${ }^{1}$ was based on accumulating evidence which suggest that neoplastic lesions that generate uncontrolled cell proliferation can also act as potent triggers of apoptosis of terminally differentiated neurons. According to this theory, terminal differentiation of neurons is associated with the suppression of cell division program but, if these cells are forced to reenter the cell cycle, they activate an aberrant cell cycle program that irreversibly will lead to cell death. Thus, it is allowed to speculate that some cell cycle components are implicated in at least some forms of neuronal apoptosis.

The present paper will review some recent data obtained in our and other laboratories with the aim both to identify and to characterize the mechanism of action of cytosolic and nuclear proteins known to be involved in cell cycle regulation as well as in promoting degeneration and apoptosis of neurons. Different molecules will be taken into consideration including members of the $\mathrm{NF}-\kappa \mathrm{B} / \mathrm{Rel}$ transcription factor family, the tumour suppressor protein p53, the cyclin-dependent kinase (cdk) inhibitor p21, and the DNA mismatch repair protein $\mathrm{MSH}$. These proteins are apparently linked by a sequential transcriptional program which suggests the existence of an intracellular pathway responsible for the induction and progression of neuronal apoptosis. We hypothesize that one of the orchestrators of such intracellular program may be the excitatory aminoacid glutamate. Glutamate is the most abundant excitatory neurotransmitter in the brain. However, under certain conditions, it may become a potent excitotoxin. ${ }^{2}$ Brain damage through excitotoxicity has been closely associated to acute conditions like stroke, trauma, hypoglycemia, but also to epilepsy and amyotrophic lateral sclerosis. In addition, a contribution of excitotoxicity to chronic and progressive neuropathologies like Alzheimer's and Parkinson's diseases has been suggested. ${ }^{3}$ Incidentally, signs of apoptosis have been associated, at least in part, with the neuronal death found in many of these diseases, including ischaemia, Parkinson's disease and Alzheimer's disease. $^{4-9}$

\section{NF- $\kappa$ B/Rel proteins}

Initially regarded as a B cell-specific transcription factor, ${ }^{10} \mathrm{NF}$ $\kappa \mathrm{B}$ was soon demonstrated to be present in an inducible form 
in most eukariotic cells where, upon stimulation by a wide variety of stimuli, it translocates to the nucleus and regulates transcription of target genes. ${ }^{11}$ Along the years, NF- $\kappa \mathrm{B}$ system has been recognized as a family of transcription factors mediating the rapid and coordinated induction of genes in response to external, primarily pathogenic stimuli. An inappropriate regulation of NF- $\kappa \mathrm{B}-$ mediated transcription has been in turn associated with pathological conditions including acute inflammatory reactions, toxic/septic shock, acute phase reactions, atherosclerosis, radiation damage, viral replication, miocardial infarction, cancer and several neuropathologies. ${ }^{12}$ The finding that proteins belonging to the NF- $\kappa \mathrm{B}$ family are also present in the central nervous system (CNS) is relatively recent. ${ }^{13}$ Of particular interest with regard to the CNS location and function of $\mathrm{NF}-\kappa \mathrm{B} / \mathrm{Rel}$ proteins is the demonstration that unlike most of the cells in periphery, except for B lymphocytes, a high constitutive NF- $\kappa \mathrm{B}$ activity can be present in neurons. For example, nuclear $\mathrm{NF}-\kappa \mathrm{B}$ specific immunostaining appeared to be present only in specific cellular subsets in rat cortex and hippocampus, while in other cell populations it is restricted to cytoplasm. In light of this observation it has been suggested that the activation state of NF- $\kappa \mathrm{B}$ might correlate with neuronal activity and that the modulator might be involved in regulation of cellular antioxidant program in metabolically very active neurons. ${ }^{13,14}$ Furthermore, neuronal $\mathrm{NF}-\kappa \mathrm{B}$ inducible activity has been demonstrated not only in neuronal bodies but also in synapses ${ }^{15-17}$ and in postsynaptic densities ${ }^{18}$ to suggest its activity as a crucial neuronal messenger carrying synaptic information to the nucleus. In the brain, NF- $\kappa \mathrm{B} /$ Rel protein expression is not restricted to neurons. These transcription factors are in fact also present, as inactive cytoplasmic form, in glial cells, including primary astrocytes, astrocytoma cell line, microglia, and Schwann cells. ${ }^{19-21}$

Still limited is the knowledge of the nature of the signals that trigger NF- $\kappa$ B activation within the CNS as well as of the target genes whose function may be relevant in brain physiology and/or pathology. Particularly interesting and relevant to our discussion is the fact that a growing body of evidence is accumulating for a specific activation of $N F-\kappa B$ proteins in both neuronal and non-neronal cells in neuropathologies associated with etiologically unrelated conditions. Activated NF- $\kappa \mathrm{B}$ has been shown in brains of patients affected by a number of neurological diseases in which apoptosis play a relevant role. The list includes Alzheimer's disease, ${ }^{22}$ Parkinson's disease, ${ }^{23}$ AIDS-Dementia complex ${ }^{24}$ and encephalitis. ${ }^{25}$ Increased NF- $\kappa$ B activity may also be associated with Ataxia Teleangectasia. ${ }^{26}$ Moreover, NF- $\kappa \mathrm{B}$ activity is induced in animal models of neurodegeneration like ischaemia, ${ }^{27}$ head trauma, ${ }^{28}$ Huntington's disease, ${ }^{29}$ and experimental allergic encephalitis. ${ }^{20}$

Numerous in vitro studies have demonstrated that diverse neurotoxic and pro-apoptotic stimuli like high concentrations of glutamate, ${ }^{30} \beta$ amyloid, ${ }^{31}$ cytokines, ${ }^{32,33}$ glycated tau, ${ }^{34} \mathrm{H}_{2} \mathrm{O}_{2},{ }^{35}$ and glucose deprivation, ${ }^{36}$ are potent activators of NF- $\kappa \mathrm{B}$ in neuronal cells. ${ }^{37-39}$ On the other hand, other in vitro studies have suggested that NF$\kappa \mathrm{B}$ activation may induce defence mechanisms against neuronal apoptosis. ${ }^{40-42}$ Understanding the contribution of $\mathrm{NF}-\kappa \mathrm{B}$ mediated transcription to neuronal death and/or survival pathways in neurological diseases represents a recently raised debate with important pharmacological implications. The relative contribution of NF- $\kappa \mathrm{B}$-mediated transcription to either survival or degeneration is likely to depend on several variables including the composition of inducible NF- $\kappa \mathrm{B}$ complexes, kinetics of activation, concomitant availability of other transcription factors and intrinsic metabolic and genetic differences between neuronal phenotypes or, within the same cell, the nature and the intensity of the activating stimulus. ${ }^{43-46}$ More knowledge is also required to understand the relative functional contribution of constitutive versus inducible NF$\kappa \mathrm{B}$ activity in gene transcription. Interestingly, it has been recently shown that partial inhibition of constitutively activated NF- $\kappa \mathrm{B}$ in fibroblasts from Ataxia Teleangectasia patients results in decreased radiation-induced apoptosis, while inhibition of NF- $\kappa \mathrm{B}$ activation in normal cells leads to increased apoptosis. ${ }^{47}$ These data can be related to those showing that suppression of steady-state, but not stimulusinduced NF- $\kappa \mathrm{B}$ activity inhibits alphavirus-induced apoptosis. ${ }^{46}$ Crucial questions arise from these observations. Are the genes 'constitutively' activated by NF- $\kappa$ B cell-specific? Also, do constitutive and inducible NF- $\kappa$ B proteins activate the same transcriptional program? Definitely, to distiguish between pro- and anti-apoptotic pathways triggered by NF$\kappa \mathrm{B}$ activation in response to a specific deleterious stimulus in specific cell phenotypes it will be crucial to identify the nature of the genes that are under the control of NF- $\kappa \mathrm{B} / \mathrm{Rel}$ factors in the CNS. Interleukin-converting enzyme, amyloid precursor protein, c-myc, and APO-1/Fas ligand are good candidates as pro-apoptotic, NF- $\kappa \mathrm{B}$ target genes. ${ }^{13,30,48}$ We have focused our interest on a particularly intriguing gene which is under transcriptional control of $\mathrm{NF}-\kappa \mathrm{B}$, the one encoding the tumour suppressor protein p53.

\section{The tumour suppressor protein p53}

The tumour suppressor protein p53 is a cell cycle checkpoint protein that contributes to the preservation of genetic stability. ${ }^{49,50}$ More recently, it was found that p53 may also play a role in cell differentiation. ${ }^{51}$

The mechanism(s) by which p53 can induce cell cycle arrest and/or apoptosis is still largely unknown. Development of transgenic mice deficient for p53 has gained further insight on the functional role of $\mathrm{p} 53 .^{52}$ Interestingly, mice homozygous for p53 null allele appear quite normal, although female-associated defects in neural closure were found at high frequency in p53 null mice embryos. ${ }^{53}$ Thus, p53 function appears to be dispensable in many apoptotic processes that occur physiologically during the entire lifespan in a large variety of organs and systems, including the brain.

A series of recent papers have contributed to unravel the positive contribution of p53 to neurodegeneration. ${ }^{54-57}$ In particular, systemic injection of kainic acid, a potent excitotoxin that produces seizures associated with a defined pattern of neuronal cell loss, induces p53 expression in neurons exhibiting morphological signs of damage. $^{56}$ More recently, Morrison et al. ${ }^{58}$ found that systemic injection of kainic acid to p53 gene deficient mice 
do not induce neuronal cell death. Hirata and Cadet ${ }^{59,60}$ have corroborated the relevance of p53 in promoting neuronal cell death program showing that homozygous p53-knockout mice are protected against neurotoxicity induced by methamphetamine. Finally, p53 expression has been investigated in Alzheimer's disease. Postmortem studies show that Alzheimer's disease brains contain higher p53 levels than age-matched controls, but it is still controversial whether the increased p53 expression is linked to apoptosis in glia or neuronal cells. ${ }^{61-63}$

\section{Excitotoxicity and apoptosis: a role for p53 and NF- $\kappa$ B proteins}

We have investigated on the role of p53 and $\mathrm{NF}-\kappa \mathrm{B}$ proteins in cultured cerebellar granule cells in response to neurotoxicity induced by glutamate. Primary cerebellar neurons offer a morphologically defined system for studying transsynaptic regulation of neuronal gene expression and provide the opportunity to analyze the precise temporal sequence of molecular events following stimulation of specific glutamate receptor subtypes. In fact, exposure of these cells for a brief period of time $(15 \mathrm{~min})$ to relatively high concentrations of glutamate (micromolar range) results in cell death which includes both necrosis and apoptosis. ${ }^{64}$ Among the intracellular events triggered by neurotoxic concentrations of glutamate is the activation of $\mathrm{NF}-\kappa \mathrm{B} / \mathrm{Rel}$ proteins. ${ }^{30}$ Functional significance of such effects has, at least in part, been suggested by the finding that under the same experimental conditions, salycilates prevent glutamate-induced neuronal death and, at the same doses, inhibit the glutamate-induced activation of NF- $\kappa$ B DNA binding activity. ${ }^{65}$ Our working hypothesis was that NF- $\kappa \mathrm{B}$ may indeed contribute to cell death triggered by glutamate by switching on pro-apoptotic target genes. Among the genes that are transcriptionally regulated by $N F-\kappa B$ is the gene encoding the tumour suppressor phosphoprotein p53. ${ }^{66}$ We then investigated the role of p53 in the glutamate-induced cell death.

We found that exposure of cerebellar granule cells to a 15 min-pulse of micromolar concentration of glutamate resulted in a significant, short-lasting increase of p53 expression. ${ }^{67}$ Previous studies performed in primary neurons have demonstrated that p53 is essential for excitotoxicity $^{57}$ and that can be induced by DNA damage. ${ }^{68}$ Our novel contribution is the demonstration of a direct link between neurotransmitter receptor stimulation and p53 induction. Measurement of p53 mRNA levels suggested that treatment of the cells with glutamate results, at least in part, in an increased p53 gene transcription. Furthermore, p53 overexpression was found to be associated with increased p53 DNA binding activity, suggesting an enhanced p53 transcriptional activity. To further support this finding, exposure of cerebellar neurons to glutamate resulted in the induction of at least two gene products that are suggested to be regulated at transcriptional level by p53, p21 and MSH2.

p21 CIP1/WAF1, an inhibitor of cdk complexes, is a well characterized transcriptional target of $\mathrm{p} 53$. It is induced by DNA damage in a p53-dependent manner and is found associated with various types of inactive cyclin-cdk complexes. ${ }^{69}$ Primary cerebellar neurons do express p21 at very low levels in basal conditions. However, very soon after a brief exposure of the cells to glutamate, p21 expression was dramatically increased and this effect lasted for several hours (unpublished data). A link between p53, p21 and proteins involved in neurodegeneration has been recently found by Roperch et al. ${ }^{70}$ who demonstrate that presenilin1 is involved in a series of model systems for p53-dependent and p53-independent apoptosis.

$\mathrm{MSH} 2$ is one of the most important proteins involved in the recognition and repair of a specific type of DNA damage that is characterized by pair mismatches. ${ }^{71}$ Up to date, very little is known about MSH2 expression in the brain. Using immunohistochemical analysis, we recently found that $\mathrm{MSH} 2$ is expressed in selective rat brain regions and it is induced by experimental paradigms of excitotoxicity. Similar results were obtained in vitro, using primary cultures of rat cerebellar granule cells. In fact, exposure of the cells to neurotoxic concentrations of glutamate resulted in a marked increase of $\mathrm{MSH} 2$ expression. ${ }^{72}$

The role of p53, p21 and MSH2 in definitely post-mitotic cells like neurons has not clearly been established. It could be speculated that $\mathrm{p} 53$ and $\mathrm{MSH} 2$ may act as sensors of DNA integrity. DNA repair is in fact intimately linked with cell cycle progression, and apoptosis is recognized as a physiological response to DNA damage. Moreover, diseases associated with germ-line mutation of genes involved in DNA damage recognition and repair, such as Ataxia Teleangectasia, present signs of neurodegeneration. A further indirect link between neurotoxicity and DNA damage has been provided by Didier et al. ${ }^{73}$ who showed accumulation of single-strand DNA damage as an early event in excitotoxicity in primary neuronal cultures. Also, this particular DNA damage results in the induction of p53 expression. $^{74,75}$

To evaluate the contribution of p53 expression to glutamate-induced cell death, we took advantage of the antisense strategy. An oligonucleotide complementary to 18

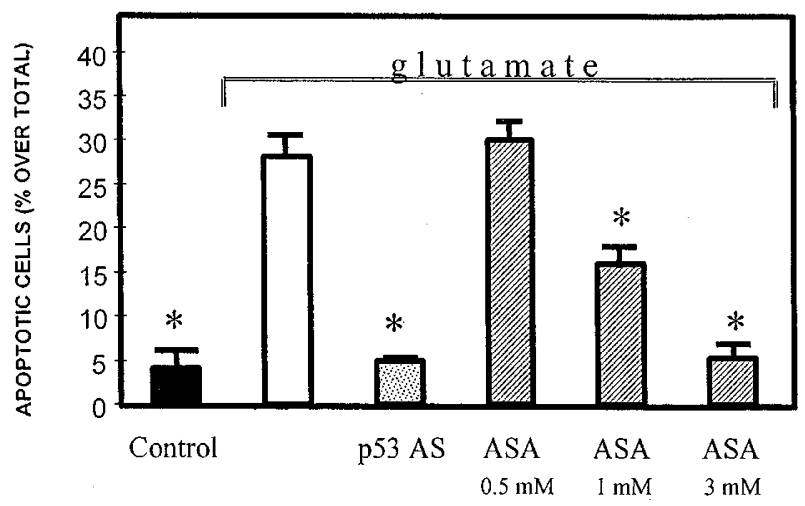

Figure 1 Prevention of glutamate-induced apoptosis in primary cerebellar neurons by a p53 antisense oligonucleotide (p53 AS) and aspirin (ASA). Apoptotic cells were visualized by TUNEL staining. p53 AS $(25 \mu \mathrm{M})$ was added to the cultures $1 \mathrm{~h}$ before the glutamate treatment. ASA, at the concentrations shown in the figure, was added 15 min before glutamate. ${ }^{*}, P<0.01$ versus glutamate-induced apoptosis 
bases flanking the ATG initiation codon of the p53 gene was synthesized and added to the culture media before treating the cells with glutamate. Blockade of p53 induction, as shown by the prevention of glutamate-induced increase of p53 immunoreactivity, resulted in a complete inhibition of the apoptotic component of the glutamate-induced cell death. ${ }^{67}$ The specificity of the effects was proven by the lack of efficacy of the sense oligonucleotide and by the observation that the antisense oligonucleotide treatment did not alter the capability of glutamate of inducing other intracellular processes, including the increase of $\mathrm{NF}-\kappa \mathrm{B}$ nuclear activity. These data support the existence of an intracellular pathway triggered by glutamate and leading to apoptosis in which p53 induction lies downstream of NF- $\kappa$ B activation. Interference of this pathway at the level of NF$\kappa \mathrm{B}$, by salycilates, or $\mathrm{p} 53$, by specific oligonucleotide antisense, results in a prevention of glutamate-induced apoptosis (Figure 1). In this experimental context, salycilates appear to possess a wider spectrum of neuroprotective activity, being also able to inhibit the glutamate-induced necrosis.

\section{Conclusions}

There is an emerging consensus that glutamate, through the activation of specific glutamate receptor subtypes, activates a series of genes whose products trigger intracellular events leading eventually to neuronal cell death. Nevertheless, the relative functional contribution of the individual gene products to the glutamate-induced neuronal death has not been completely clarified. We suggest that glutamate, possibly by increasing intracellular calcium concentration and/or oxygen free radicals production, may activate a restricted number of transcription factors which in turn amplify the signal by recruiting other genes to dictate specific transcriptional programs. A hierarchy of intervention is likely to occur. We propose that $\mathrm{NF}-\kappa \mathrm{B}$ proteins are among the initial orchestrators of the glutamate-induced apoptotic program. Downstream NF- $\kappa \mathrm{B}$-activation is the transcription factor $\mathrm{p} 53$. At the present time, the p53 target genes triggered by glutamate receptor stimulation are largely unknown. We hypothesize that up-regulation of p21 and $\mathrm{MSH} 2$ genes, in the experimental paradigm of glutamate-induced neuronal death, is one of the consequences of the increased transcriptional activity of p53. On these bases, we propose that $\mathrm{NF}-\kappa \mathrm{B}, \mathrm{p} 53, \mathrm{p} 21$ and $\mathrm{MSH} 2$ could be relevant contributors to the glutamate-induced neuronal apoptosis. The fact that these proteins are also involved in cell cycle regulation supports the hypothesis that aberrant expression of mitotic proteins participates in neuronal cell death program. Further studies will be necessary for understanding whether other molecules which are known to be involved in

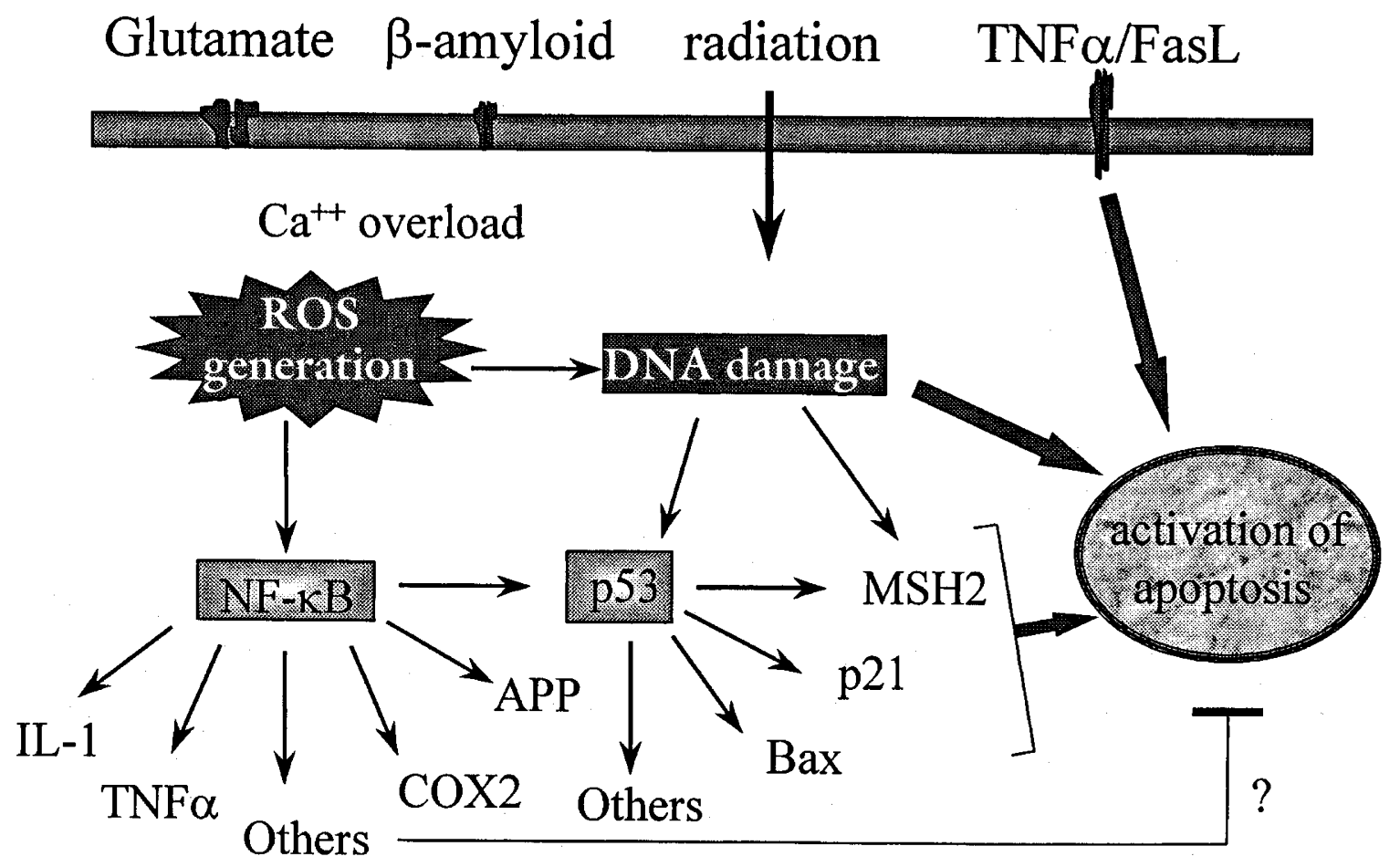

Figure 2 Schematic representation of the intracellular events activated by various apoptotic signals including glutamate, $\beta$-amyloid, various types of irradiation and TNF $\alpha / F a s$ ligand. According to our hypothesis, stimulation of ionotropic glutamate receptor by glutamate or exposure to $\beta$-amyloid, although with different mechanisms, results in increased intracellular $\mathrm{Ca}^{2+}$ concentrations and reactive oxygen species (ROS). These effects may all converge ultimately on $\mathrm{NF}-\kappa \mathrm{B}$ activation. In the nucleus, NF- $\kappa$ B may induce, together with other transcription factors, a number of genes which could activate intracellular programs leading to either apoptosis or neuroprotection. Factors affecting such choice are at the moment unknown. Among the apoptotic genes activated by NF- $\kappa$ B is p53 which may activate the transcription of other genes, including $\mathrm{MSH} 2$ and $\mathrm{p} 21$, to progress the apoptotic pathway. Induction of the p53 gene can also occur independently of $\mathrm{NF}-\kappa \mathrm{B}$ and by direct recognition of damaged DNA. This tentative scheme takes into consideration the occurrence of p53-independent apoptosis which can be triggered by other signals including TNF $\alpha / F$ as ligand or DNA damage 
transformation and degeneration processes, such as members of the bcl-2 family and caspases, are active participants in the NF- $\kappa$ B-induced, p53-mediated pro-apoptotic pathway.

Finally, the glutamate-induced apoptosis of primary neuronal cultures was found strictly p53-dependent. This is not a generalized phenomenon. As an example, apoptosis of cerebellar neurons in vitro induced by serum deprivation or low potassium is p53-independent. ${ }^{76}$ Moreover, different genotoxic treatments may cause distinct phosphorylation of $\mathrm{p53}$, which may account for the activation of unique pro-apoptotic pathways. ${ }^{77}$ In all, these data support the view that different intracellular programs leading to neuronal apoptosis may exist. It could be inferred that the apoptosis that occurs physiologically (i.e. during brain development and ageing) and the apoptosis that is related with neurodegenerative diseases may depend on different molecular participants. This particular topic definitely requires much attention in the development of anti-neurodegenerative drugs acting at transcriptional level. Understanding this cascade of nuclear events may indeed unravel specific targets for pharmacological intervention for those neurological diseases in which specific types of apoptosis play a relevant role.

\section{References}

1. Heintz N (1993) Cell death and the cell cycle: a relationship between transformation and neurodegeneration? TiBS. 18: 449-451

2. Choi DW (1988) Glutamate neurotoxicity and diseases of the neurons system. Neuron. 1: 623-634

3. Lipton SA and Rosemberg PA (1994) Excitatory aminoacids as a final common pathway for neurologic disorders. N. Engl. J. Med. 330(9): 613-622

4. Robbins JH, Otsuka F, Tarone RE, Polinsky RJ, Brumback RA and Nee LE (1985) Parkinson's disease and Alzheimer's disease: hypersensitivity to X rays in cultured cell lines. J. Neurol. Neurosurg. Psychiatry 48: 916-923

5. DuguidJR, Bohmot CW, Liu Nand Tourtellotte WW (1989) Changes in braingene expression shared by scrapie and Alzheimer's disease. Proc. Natl. Acad. Sci. USA 86: 7260-7264

6. Mazzarello P, Poloni M, Spadari S andFocher F (1992) DNA repair mechanism in neurological diseases: facts and hypotheses. J. Neurological Sci. 112: 4-14

7. Boerrigter METI, WeiJY and Vijg J(1992) DNA repair and Alzheimer's disease. J. Gerontol. 47: B177-B184

8. Portera-Cailliau C, Hedreen JC, Price DL and Koliatsos VE (1995) Evidence of apoptotic cell death in Huntington disease and excitotoxic animal model. J. Neurosci. 15: 3775-3787

9. Liu PK, Hsu CY, Dizdaroglu M, Floyd RA, Kow YW, Karakaya A, Rabow LE and Cui J-K (1996) Damage, repair, and mutagenesis in nuclear genes after mouse forebrain ischemia-reperfusion. J. Neurosci. 16: 6795-6806

10. Sen R and Baltimore D (1986) Multiple nuclear factors interact with the immunoglobulin enhancer sequences. Cell 46: 705-716

11. Grilli M, Chiu JJS and Lenardo MJ (1993) NF- $\kappa B$ and Rel: Participants in a Multiform Transcriptional Regulatory System. Intern. Rev. Citol. 143: 1-62

12. Baldwin AS (1996) The NF- $\kappa$ B and $I_{\kappa} B$ proteins: new discoveries and insights. Annu. Rev. Immunol. 14:649-681

13. O' Neill LAJ and Kaltschmidt C (1997) NF- $\kappa$ B: a crucial transcription factor for glial and neuronal cell function. TiNS. 20: 252-258

14. Kaltschmidt C, KaltschmidtB, Neumann H, Wekerle H and Baeuerle PA (1994a) Constitutive NF- $\kappa$ B activity in neurons. Mol. Cell Biol. 14: 3981-3992

15. Kaltschmidt C, Kaltschmidt $B$ and Baeuerle PA (1993) Brain synapses contain inducible forms of the transcription factor NF- $\kappa$ B. Mech. Development 43: $135-$ 147

16. Guerrini I, Blasi F and Denis-Donini S (1995) Synaptic activation of NF- $k$ B by glutamate in cerebellar granule neurons in vitro. Proc. Natl. Acad. Sci. USA. 92 9077-9081
17. Medberg PJ, Kinney WR, Valcourt EG and Routtenberg A (1996) Gene expression of the transcription factor NF- $\kappa B$ in hippocampus: regulation by synaptic activity. Mol. Brain Res. 38: 179-190

18. Suzuki T, Mitake S, Okumura-Noji K, Yang JP, Fujii T and Okamoto T (1997) Presence of $\mathrm{NF}-\kappa \mathrm{B}$-like and $\mathrm{I}_{\kappa} \mathrm{B}$-like immunoreactivities in postsynaptic densities. Neuroreport. 8: 2931-2935

19. Sparacio SM, Zhang Y, Vilcek J and Benveniste EN (1992) Cytokine regulation of Interleukin 6 gene expression in astrocytes involves activation of an NF-kappaBlike nuclear protein. J. Neuroimmunol. 39: 231-242

20. Kaltschmidt C, Kaltschmidt B, Lannes-Vieira J, Kreutzberg GW, Wekerle H, Baeuerle PA and Gehrmann J (1994b) Transcription factor NF- $\kappa$ B is activated in microglia during experimental autoimmune encephalomyelitis. J. Neuroimmunol. 55: $99-106$

21. Carter BD, Kaltschmidt C, Kaltschmidt B, Offenhauser N, Bonn-Matthaei R, Baeuerle PA and Barde Y-A (1996) Selective activation of NF-kappa B by nerve growth factor through the neurotrophin receptor p75. Science 272: 542-545

22. Yan SD, Chen X, FuJ, Chen M, Zhu H, RoherA, Slattery T, Zhao L, Nagashima M, Morser J, Migheli A, Nawroth P, Stern D and Schmidt AM (1996) RAGE and amyloid- $\beta$ peptide neurotoxicity in Alzheimer's disease. Nature 382: 685-691

23. Hunot S, Brugg B, Ricard D, MichelPP, Muriel MP, Ruberg M, Faucheux BA, Agid $Y$ and Hirsh EC (1997) Nuclear translocation of NF- $k B$ is increased in dopaminergic neurons of patients with Parkinson disease. Proc. Natl. Acad. Sci. USA 94: 7531-7536

24. Atwood WJ, Tornatore CS, Traub R, Conant K, Drew PD and Major EO (1994) Stimulation of HIV type 1 gene expression and induction of NF-kappa B (p50/ p65)-binding activity in tumor necrosis factor alpha-treated human fetal glial cells. AIDS Res. Hum. Retroviruses 1: 1207-1211

25. Dollard SC, James HJ, Sharer LR, Epstein LG, Gelbard HA and Dewourst S (1995) Activation of nuclear factor-kappa B in brains from children with HIV-1 encephalitis. Neuropathol. Appl. Neurobiol. 21: 518-528

26. Jung M, Zhang Y, Lee S and Dritschilo A, (1995) Correction of radiation sensitivity in ataxia teleangectasia cells by truncated $\mathrm{I}_{\kappa} \mathrm{Ba}$. Science 268 : $1619-$ 1621

27. Clemens JA, Stephenson DT, Yin T, Smalstig ER, Panetta JA and Little S (1998) Drug-induced neuroprotection from global ischemia is associated with prevention of persistent but not transient activation of nuclear factor-kB in rats. Stroke 29: 677-682

28. Yang K, Mu XS and Hayes RL (1995) Increased cortical nuclear factor-kappa B (NF-kappa B) DNA binding activity after traumatic brain injury in rats. Neurosci. Letts. 19: 101-104

29. Quin ZH, Wang Y, Nakai M and Chase T (1998) Nuclear factor-kappa B contributes to excitotoxin-induced apoptosis in rat striatum. Mol. Pharmacol. 53: $33-42$

30. Grilli M, Goffi F, Memo M and Spano PF. (1996a) Interleukin-1 $\beta$ and glutamate activate the NF- $\kappa \mathrm{B} / \mathrm{Rel}$ binding site from the regulatory region of the amyloid precursor protein gene in primary neuronal cultures. J. Biol. Chem. 271:15002 15007

31. Kaltschmidt B, Uherek M, Volk B, Baeuerle PA and Kaltschmidt C (1997) Transcription factor $\mathrm{NF}-\kappa \mathrm{B}$ is activated in primary neurons by amyloid $\beta$ peptides and in neurons surrounding early plaques from patients with Alzheimer disease. Proc. Natl. Acad. Sci. USA 94: 2642-2647

32. Kessler JA, Ludham WH, Freidin MM, Hall DH, Michaelson MD, Spray DC, Dougherty M and Batter DK (1993) Cytokine-induced programmed cell death of cultured sympathetic neurons. Neuron. 11: 1123-1132

33. Talley AK, Dewurst S, Perry SW, Dollard SC, Gummuluru S, Fine SM, New D, Epstein LG, Gendelman BE and Gelbard HA(1995) Tumornecrosis factor alphainduced apoptosis in human neuronal cells: protection by the antioxidant $\mathrm{N}$ acetylcysteine and the genes bcl-2 and crm-A. Mol. Cell. Biol. 15: 2359-2366

34. Yan SD, Yan SF, Chen X, Fu J, Chen M, Kuppusamy P, Smith MA, Perry G, Godman GC, Nawroth P, Zweier JL and Stern D (1995) Non-enzymatically glycated tau in Alzheimer's disease induces neuronal oxidant stress resulting in cytokine gene expression and release of amyloid $\beta$-peptide. Nat. Med. 1:693699

35. Whittemore ER, Loo DT and Cotman CV (1994) Exposure to hydrogen peroxide induces cell death via apoptosis in cultured rat cortical neurons. Neuroreport. 5: $1485-1488$

36. Tong $L$ and Perez-Polo JR (1995) Transcription factor DNA binding activity in PC12 cells undergoing apoptosis after glucose deprivation. Neurosci. Lett. 191: 137-140 
37. Abbadie C, Kabrun N, Bouali F, Smardova J, Stehelin D, Vandenbender B and Enrietto PJ (1993) High levels of c-rel expression are associated with programmed cell death in the developing avian embryo and in bone marrow cells in vitro. Cell 75: 899-912

38. Lin KI, Lee SH, Narayanan R, Baraban JM, Mardwick JM and Ratan RR (1995) Thiol agents and Bcl-2 identify an alphavirus-induced apoptotic pathway that requires activation of the transcription factor NF-kappa B. J. Cell Biol. 131: $1149-1161$

39. Grimm S, Bauer MK, Baeuerle PA and Shulze-Osthoff K (1996) Bcl-2 downregulates the activity of transcription factor NF-kappa B induced upon apoptosis. J. Cell Biol. 134: 13-23

40. Barger SW, Horster D, Furukawa K, Goodman, Y, Krieglstein J and Mattson MP (1995) Tumor Necrosis Factor alpha and beta protect neurons against amyloid beta-peptide toxicity: evidence for involvement of a kappa B-binding factor and attenuation of peroxide and $\mathrm{Ca}^{2+}$ accumulation. Proc. Natl. Acad. Sci. USA 92: 9328-9332

41. Barger SW and Mattson MP (1996) Induction of neuroprotective $\kappa$ B-dependent transcription by secreted forms of the Alzheimer's $\beta$-amyloid precursor. Brain Res. Mol. Brain Res. 40: 116-126

42. Lezoualc'h F, Sagara Y, Holsboer F and Behl C (1998) High constitutive NF- $\kappa$ B activity mediates resistance to oxidative stress in neuronal cells. J. Neurosci. 18: $3224-3232$

43. Baichwal M and Baeuerle PA (1997) Activate NF-kappa B or die ? Curr. Biol. 7: 94-96

44. Grilli Mand Memo M (1997) Transcriptional pharmacology of neurodegenerative disorders: novel venue towards neuroprotection against excitotoxicity? Molecular Psychiatry 2: $192-194$

45. Grilli M and Memo M (1998) NF- $k$ B/Rel proteins: a point of convergence of signalling pathways relevant in neuronal function and dysfunction. Biochem Pharmacol 56: in press

46. Lin KI, DiDonato JA, Hoffmann A, Hardwick J and Ratan RR (1998) Suppression of steady-state, but not stimulus-induced NF-kappaB activity inhibited alphavirus-induced apoptosis. J. Cell Biol. 141: 1479-1487

47. Jung M, Zhang Y, Dimtchev A and Dritschilo A (1998) Impaired regulation of Nuclear Factor- $\mathrm{kB}$ results in apoptosis induced by gamma radiation. Radiation Res. 149: 596-601

48. Bauer MKA, Vogt M, Los M, SiegelJ, Wesselborg S and Shulze-Osthoff K(1998) Role of reactive oxigen intermediates in activation-induced CD95 (APO-1/Fas) ligand expression. J. Biol. Chem. 273: 8048-8055

49. Lane DP (1992) Cancer. p53, guardian of the genome. Nature 358: 15-16

50. Vogelstein Band Kinzier KW (1992) p53function and dysfunction. Cell, 70:523526

51. Almog N and Rotter V (1997) Involvement of p53 in cell differentiation and development. Biochem. Biophys. Acta. 1333: 1-27

52. Donehover LA, Harvey M, Slagle BL, McArthur MJ, Montgomery Jr CA, Butel JS and Bradley $A$ (1992). Mice deficient for p53 are developmentally normal but susceptible to spontaneous tumours. Nature 356: 215-221

53. Armstrong JF, Kaufman MH, Harrison DJ and Clarke AR (1995) High-frequency developmental abnormalities in p53-deficient mice. CurrentBiology 5: 931-936

54. Chopp M, Li Y, Zhang ZG and Freytag SO (1992) p53 expression in brain after middle cerebral artery occlusion in the rat. Biochem Biophys. Res. Commun. 182: $1201-1207$

55. Li Y, Chopp M, Zhang ZG, Zaloga C, Neiwenhuis L and Gautam S (1994) p53immunoreactive protein and p53 mRNA expression after transient middle cerebral artery occlusion in rats. Stroke 25: 849-855

56. Sakhi S, Bruce A, Sun N, Tocco G, Baudry M and Schreiber SS (1994) p53 induction is associated with neuronal damage in the central nervous system. Proc. Natl. Acad. Sci. USA. 89: 12028-12032

57. Xiang H, Hochman DW, Saya H, Fujiwara T, Schwartzkroin PA and Morrison RS (1996) Evidence for p53-mediated modulation of neuronal viability. J. Neurosci. 16: $6753-6765$
58. Morrison RS, Wenzel HJ, Kinoshita Y, Robbins CA, Donehower LA and Schwartzkroin PA (1996) Loss of the p53 tumor suppressor gene protects neurons from kainate-induced cell death. J. Neurosci. 16: 1337-1345

59. HirataHand CadetJL (1997a)p53-knockoutmice are protectedagainst the longterm effects of methamphetamine on dopaminergic terminals and cell bodies. J. Neurochem. 69: 780-790

60. Hirata $\mathrm{H}$ and Cadet $\mathrm{JL}$ (1997b) Methamphetamine-induced serotonin neurotoxicity is attenuated in p53-knockout mice. Brain Res. 768: 345-348

61. Kitamura Y, Shimohama S, Kamoshima W, Matsuoka Y, Nomura $Y$ and Taniguchi T (1997) Changes of p53 in the brains of patients with Alzheimer's disease. Biochem. Biophys. Res. Commun. 232: 418-421

62. de la Monte SM, Sohn YK and Wands JR (1997) Correlates of p53- and Fas(CD95)-mediated apoptosis in Alzheimer's disease. J. Neurol. Sci. 152: $73-$ 83

63. Nagy Z, Esiri MM and Smith AD (1997) Expression of cell division markers in the hippocampus in Alzheimer's disease and other neurodegenerative conditions. Acta. Neuropathol. (Berl). 93: 294-300

64. Nicotera P, Ankarcrona M, Bonfoco E, Orrenius S and Lipton SA (1997) Neuronal necrosis and apoptosis: two distinct events induced by exposure to glutamate or oxidative stress. Adv. Neurol. 72: 95-101

65. Grilli M, Pizzi M, Memo M and Spano PF (1996b) Neuroprotection by salicylate through blockade of NF- $\kappa$ B activation. Science 274: 1383-1385

66. Wu H and Lozano G (1994) NF- $\kappa$ B activation of $\mathrm{p} 53$. A potential mechanism for suppressing cell growth in response to stress. J. Biol. Chem. 269:20067-20074

67. Uberti D, Belloni M, Grilli M, Spano PF and Memo M (1998) Induction of tumour suppressor phosphoprotein p53 in the apoptosis of cultured rat cerebellar neurons triggered by excitatory aminoacids. Eur. J. Neurosci. 10: 245-256

68. Enokido Y, Araki T, Tanaka Kand Hatanaka H (1996) Involvement of p53 in DNA strand break-induced apoptosis in postmitotic CNS neurons. Eur. J. Neurosci. 8: $1812-1821$

69. El-Deiry WS, Tokino T, Veculescu VE, Levy DB, Parsons R, Trent JM, Lin D, MercerWE, Kinzler KW and Vogelstein B (1993) WAF1, a potent mediator of p53 tumor suppression. Cell 75: 817-825

70. Roperch J-P, Alvaro V, Prieur S, Tuynder M, Nemani M, Lethrosne F, Piouffre L, Gendron M-C, Israeli D, Dausset J, Oren M, Amson R and Telerman A (1998) Inhibition of presenilin 1 expression is promoted by p53 and p21 $1^{\mathrm{WAF}-1}$ and results in apoptosis and tumor suppression. Nat. Med. 4: 835-838

71. Palombo F, Hughes M, Jiricny J, Truong O and Hsuan J (1994) Mismatch repair and cancer. Nature 367: 417-418

72. Belloni M, Uberti D, Rizzini C, Torsello A, Spano P.F and Memo M (1997) Kainic acid activation of the DNA mismatch repair protein $\mathrm{MSH} 2$ in rat brain. Soc. Neurosci. Abstr. 23: 2218

73. Didier M, Bursztajn S, Adamec E, Passani L, Nixon RA, Coyle JT, Wei JY and Berman SA (1996) DNA strand breaks induced by sustained glutamate excitotoxicity in primary neuronal cultures. J. Neurosci. 16: 2238-2250

74. Jayaraman JL and Prives C. (1995) Activation of p53 sequence-specific DNA binding by short single strand of DNA requires the p53 C-terminus. Cell 81 : $1021-1029$

75. Lee S, Elenbaas B, Levine A and Griffith J (1995) p53 and its 14 kDa C-terminus domain recognize primary DNA damage in the form of insertion/deletion mismatches. Cell 81: 1013-1020

76. Eizenberg O, Faber-EIman A, GottlierE, Oren M, Rotter V and Schwartz M (1996) p53 plays a regulatory role in differentiation and apoptosis of central nervous system-associated cells. Mol. Cell. Biol. 16: 5178-5185

77. Kobayashi T, Ruan S, JabburJR, ConsoliU, Clodi K, Shiku H, Owen-Schaub LB, Andreeff M, Reed JC and Zhang W (1998) Differential p53 phosphorylation and activation of apoptosis-promoting genes Bax and Fas/APO-1 by irradiation and ara-C-treatment. Cell Death \& Differ. 5: 584-591 